\title{
POSITIVE ORIENTATION AND GENERALIZED SELF-EFFICACY
}

Piotr K. OLEŚ ${ }^{1}$, Guido ALESSANDRI ${ }^{2}$, Maria OLES' ${ }^{1}$, Wacław BAK ${ }^{1}$, Tomasz JANKOWSKI ${ }^{1}$, Mariola LAGUNA ${ }^{1}$, Gian Vittorio CAPRARA ${ }^{2}$

${ }^{1}$ Institute of Psychology, The John Paul II Catholic University of Lublin Al. Raclawickie 14, 20-950 Lublin, Poland

E-mail: oles@kul.lublin.pl

${ }^{2}$ Department of Psychology, Sapienza, University of Rome

\begin{abstract}
The beliefs that people hold about themselves, their life and future are important and mutually related constituents of psychological functioning and well-being. In this paper, we investigated the relationship between positive orientation and generalized self-efficacy. The sample consisted of 672 participants aged 15-72 years (274 males). The results confirmed the first hypothesis that positive orientation and generalized self-efficacy constitute two distinct but correlated constructs. The results were confirmed across the three age groups and, contrary to the second hypothesis, age was not confirmed as a moderator of the relationship between positive orientation and self-efficacy.
\end{abstract}

Key words: positive orientation, self-esteem, life satisfaction, optimism, generalized self-efficacy

Interest in the positive beliefs and positive features of individual functioning has been attracting an increasing amount of attention over the last decade. The promotion of health rests upon a broad appreciation of the potentials and strengths that enable people to recognize their talents, to act fruitfully, to cope effectively, and to pursue ambitious goals (Lyubomirsky, King, Diener, 2005; Sheldon, 2009).

Positive orientation is the name given to what life satisfaction, self-esteem, and optimism have in common. It is a pervasive mode of facing reality, reflecting upon experience, framing events, and processing experiences (Caprara et al., 2009). This study addresses the question of whether generalized self-efficacy beliefs (Schwarzer, 1992) can be included in the aforementioned triad, as an in- dicator of positive orientation. The aim of this article is twofold. The first is to check whether self-efficacy beliefs belong to the broader construct of positive orientation; the second is to check whether the relationships between positive orientation and self-efficacy are moderated by age.

\section{Positive Orientation as a Personality Dimension}

Recently, a significant body of research has focused on human strengths and optimal functioning (Csikszentmihalyi, 2009; Sheldon, 2009; Sollárová, Sollár, 2010). Selfesteem (Kernis, 2003), life satisfaction (Diener, 1984) and dispositional optimism (Carver, Scheier, 2002) are treated as associated with well-being and success and con-

DOI: $10.21909 /$ sp.2013.01.620 
stitute the core of positive attitudes towards the world and the self(Caprara et al., 2010).

Life satisfaction refers to one's overall evaluation of various domains, as well as to relationships that make one's life meaningful (Diener, 1984). It is associated with numerous positive outcomes, including physical health and use of adaptive coping strategies (Jones et al., 2003). Self-esteem expresses the general evaluation of oneself (Rosenberg, 1989) and many research findings attest to the adaptive role of high selfesteem (Baumeister et al., 2003). Dispositional optimism refers to a belief about future events according to which good things will be plentiful and bad things will be scarce, which has positive effects in various settings and life circumstances (Carver, Scheier, 2002). Although various studies document a relatively high degree of correlation between the three aforementioned constructs (Diener, Diener, 1995; Schimmack, Diener, 2003), most of the literature focuses on their unique role in producing specific outcomes (e.g., Laguna, in press; Žitný, Halama, 2011; SarmánySchuller, 1993).

A recent line of research investigates the degree to which self-esteem, life satisfaction and optimism can be subsumed under a common latent dimension. A relatively large body of findings revealed the existence of positive orientation (POS) as a higher-order construct that captures the core of self-esteem, life satisfaction, and optimism across cultures as well. (Caprara et al., in press). Genetic studies (Caprara et al., 2009) together with longitudinal and cross-sectional findings (Alessandri, Caprara, Tisak, 2012; Caprara et al., 2010) point out positive orientation as a basic predisposition that accounts, to a considerable extent, for individual adjustment and achievement. Thus, a common factor underlying mutual relationships among these three variables and explaining the level of self-esteem, life satisfaction, and optimism can be introduced as the basis for positive beliefs about the self - its value, future, and current status.

The basic idea of Positive Orientation theory is that an optimistic view of oneself, life, and the future is a basic predisposition allowing people to cope successfully with life despite adversities, failures, and losses. The empirical findings from different populations (i.e., Canada, Italy, Germany, and Japan), show that the positive judgments people hold about the themselves, life, and the future can be traced to a higher-order dimension (Caprara et al., 2009). Yet, the models including other personal characteristics that could be associated with self-esteem, life satisfaction, and optimism - e.g., trust or emotional stability - demonstrate worse model fit indices than the proposed POS model (Caprara, Alessandri, Barbaranelli, 2010). However, the question remains of what variables constitute positive orientation.

\section{Positive Orientation and Generalized Self-Efficacy}

In this study we examine the relationships between generalized self-efficacy beliefs (GSE) and POS. The concept of self-efficacy applies to the judgments people hold about their capacity to master specific tasks and to cope with challenging situations. In contrast to Bandura (1997) who advocates the specific character of self-efficacy, Schwarzer (1992) claims that GSE, as a general confidence in one's own ability to take necessary action in challenging situations, is particularly useful. As several studies list GSE among the correlates of adjustment 
(Schwarzer, 1992; Akin, Kurbanoglu, 2011), we wonder whether it should also be included among the first-order indicators of POS. Previous findings show significant correlations between GSE and each of the three components of POS when these are treated separately (Luszczynska, Scholz, Schwarzer, 2005; Magaletta, Oliver, 1999). While selfesteem, optimism, and life satisfaction are general evaluations of oneself, life, and the future, GSE concerns the impact people believe themselves to be able to exert on their environment. That is why one may consider three alternative hypotheses: 1) self-esteem, life satisfaction, optimism, and GSE are separate but correlated constructs; 2) POS is composed of all four variables; 3) GSE and POS represent two distinct but related personality dimensions. Our hypothesis is the following:

Hypothesis 1. Positive orientation and generalized self-efficacy represent two different but personality dimensions.

Taking developmental processes into account, one can expect different relationships between POS and self-efficacy across age groups. Although general satisfaction with life, hope, optimism, and self-esteem as well as self-efficacy are interrelated in adolescents (Frydenberg, 2008; Semmer, 2006; Jombiková, Kováč, 2007), their mutual relations are rather vague. For example, self-esteem slightly increases during adolescence and early adulthood (Baumeister et al., 2003), whereas self-efficacy beliefs are related to successes and failures in adolescents' efforts to gain control over the effects of their own actions (Rew, 2005). Practicing self-efficacy through an interaction with the environment and coping with stress, adolescents learn how to control their lives and how to master desired changes, which in turn influences their self-efficacy beliefs (Frydenberg, 2008). Personality structure, incompletely integrated in the period of identity formation, becomes more integrated in young adults (Heckhausen, 1999); thus, dimensions relatively separate for adolescents may merge into unified structures for adults. Assuming the development of personal beliefs, we postulate that:

Hypothesis 2. Age is the moderator of the relationships between positive orientation and generalized self-efficacy.

\section{THE PRESENT CONTRIBUTION}

The aim of this study is to check whether self-efficacy belongs to the broader construct of positive orientation and whether the relationships between positive orientation and self-efficacy are moderated by age. This study outlines the relation between POS and GSE using the Structural Equation Modeling (SEM) approach. Following a suggestion by Edwards (2001), we examine the fit of three competing SEM models (Figure 1). The first one, Model 1, posits a single latent dimension loaded by self-esteem, life satisfaction, and optimism, which is correlated with general self-efficacy. This model represents a tau equivalent model (i.e., the first-order indicators have equal loadings on the latent factor), with POS and GSE as correlated but distinct dimensions. Imposing the constraint of equality on the factor loadings of selfesteem, life satisfaction, and optimism is essential in order to make the measurement model for POS over-identified. Model 2, posits a single latent dimension equally loaded by self-esteem, life satisfaction, optimism, and GSE. Finally, Model 3 is built and considered as a reference model in which four variables are distinct but correlated con- 
structs. Following Edwards (2001), we select the model that fits equally well or better than Model 3 and better than the other competitive model. We assume (H1) that Model 1, positing POS correlated with GSE, produces the best fit to the data.

To achieve the second aim of this study, we repeated the complete analysis procedure by dividing the total group into three age subgroups: adolescents, students, and adults. The same sequence of models was retested and compared separately in each sample. Having ascertained the best-fitting model, we examined its measurement invariance by estimating its parameters across the three samples. Since positive orientation was posited as a stable personality characteristic (Caprara et al., 2009), we hypothesized
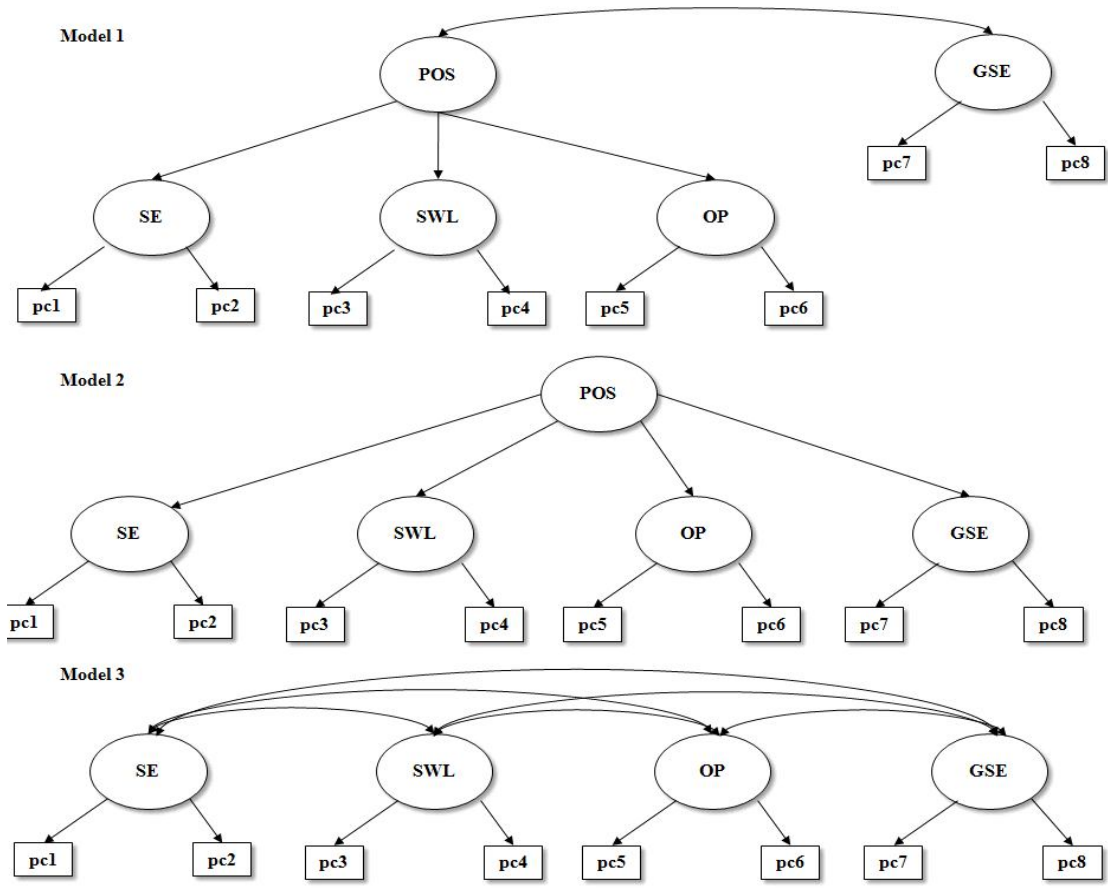

Figure 1. Three models tested: Model 1: POS correlated with GSE; Model 2: POS loaded by GSE; Model 3: Correlated constructs model.

Note: $\mathrm{SE}=$ self-esteem; $\mathrm{SWL}=$ life satisfaction; $\mathrm{OP}=$ optimism; $\mathrm{GSE}=$ generalized selfefficacy; Pc1-Pc2: parcels for self-esteem; Pc3-Pc4: parcels for life satisfaction; Pc5-Pc6: parcels for optimism; Pc7-Pc8: parcels for GSE. 
that Model 1 should outperform the other models in this case as well. Moreover, age and gender differences in self-esteem, life satisfaction, and GSE, were investigated in an explorative manner.

\section{METHOD}

\section{Participants and Procedure}

The participants were 672 Polish people (274 males, $41 \%$ ), ranging in age from 15 to 72 years $(M=27.46 ; S D=12.51)$. Education ranged from 8 till 25 years $(\mathrm{M}=14.5, \mathrm{SD}=$ 3.00 ) - from primary school to academic degree; $23 \%$ were married. All participants were contacted personally by trained researchers and filled out a set of questionnaires. All measures were completed anonymously to ensure confidentiality; the instruments were given in the same order as described below.

For further analyses, the total sample was divided into three subgroups: 1) adolescents $(\mathrm{n}=200 ; 80$ males, $40 \%)$, with a mean age of 16.81 years $(\mathrm{SD}=0.69) ; 2)$ students $(\mathrm{n}=232$; 111 males, $48 \%$ ), with a mean age of 21.88 years $(\mathrm{SD}=1.92)$, and 3$)$ adults $(\mathrm{n}=240$; 83 males, $35 \%$ ), with a mean age of 41.74 $(\mathrm{SD}=10.28)$

\section{Instruments}

Three scales measuring three components ofPOS and a scale measuring GSE were used.

Rosenberg's Self Esteem Scale (RSES) is a 10-item scale (Rosenberg, 1989). Participants indicated the extent to which they felt they possessed positive qualities using a 4-point scale (1 - strongly disagree, 4 strongly agree). Cronbach's alpha coefficients were: .83, .83, and .82 for adolescent, student, and adult samples, respectively.
Satisfaction with Life Scale (SWLS) consists of 5 items (Diener et al., 1985). Participants rated the extent to which they felt generally satisfied with life on a 7-point scale (1 - strongly disagree, to 7 -strongly agree). The alphas were: .81, .80 and .80 for adolescents, students, and adults, respectively.

Life Orientation Test (LOT-R) is a 10-item scalewith 6items measuringoptimism(Scheier, Carver, Bridges, 1994). Participants provided their ratings using a 5-point scale (1-strongly disagree, to 5-strongly agree). The alphas were: $.73, .75$, and .71 , for adolescent, student, and adult samples, respectively.

General Self-Efficacy Scale (GSES) is a 10 -item scale to measure generalized self-efficacy beliefs (Schwarzer, Jerusalem, 1995). Respondents rated to what extent each statement was true for them across a 4-point Likerttype scale $(1-$ not at all true, to 4 - exactly true). The alphas were: $.83,84$, and .82 , respectively, for adolescents, students, and adults.

\section{RESULTS}

Table 1 presents the means, standard deviations, and significance of the ANOVA main effects of age group membership and gender, as well as of the interaction between group and gender on self-esteem, life satisfaction, optimism, and GSE. Only mean level of self-esteem and optimism appeared to vary across groups. In particular, according to Tukey's post hoc tests, adults appeared to score higher than young adults and adolescents on both self-esteem and optimism. However, no differences were observed among adolescents and young adults on these variables. Finally, neither gender nor interaction effects were detected for any of the variables. 
Table 1. Means, standard deviations, and ANOVA results of self-esteem, life satisfaction, optimism, and generalized self-efficacy for adolescents, students, adults and by sex

\begin{tabular}{|c|c|c|c|c|c|c|c|c|}
\hline \multirow{2}{*}{ Self-Esteem } & \multicolumn{2}{|c|}{ Males } & \multicolumn{2}{|c|}{ Females } & \multicolumn{4}{|c|}{ ANOVA results } \\
\hline & $\mathrm{M}$ & SD & $\mathrm{M}$ & $\mathrm{SD}$ & Variables & $\mathrm{F}$ & $\mathrm{p}$ & $\eta^{2}$ \\
\hline Adolescents & 3.54 & .55 & 3.54 & .60 & group & 6.39 & $<.01$ & .02 \\
\hline Students & 3.67 & .45 & 3.59 & .58 & $\operatorname{sex}$ & .60 & .42 & .01 \\
\hline Adults & 3.77 & .58 & 3.75 & .47 & group*sex & .42 & .66 & .01 \\
\hline \multirow{2}{*}{$\begin{array}{l}\text { Life } \\
\text { Satisfaction }\end{array}$} & \multicolumn{2}{|c|}{ Males } & \multicolumn{2}{|c|}{ Females } & \multicolumn{4}{|c|}{ ANOVA results } \\
\hline & $\mathrm{M}$ & $\mathrm{SD}$ & $\mathrm{M}$ & $\mathrm{SD}$ & Variables & $\mathrm{F}$ & $\mathrm{p}$ & $\eta^{2}$ \\
\hline Adolescents & 5.00 & 1.30 & 4.45 & 1.57 & group & .88 & .45 & .01 \\
\hline Students & 5.30 & 1.37 & 5.09 & 1.3 & $\operatorname{sex}$ & .05 & .82 & .01 \\
\hline Adults & 5.34 & 1.46 & 4.07 & 1.34 & group*sex & .90 & .41 & .01 \\
\hline \multirow{2}{*}{ Optimism } & \multicolumn{2}{|c|}{ Males } & \multicolumn{2}{|c|}{ Females } & \multicolumn{4}{|c|}{ ANOVA results } \\
\hline & $\mathrm{M}$ & SD & $\mathrm{M}$ & $\mathrm{SD}$ & Variables & $\mathrm{F}$ & $\mathrm{p}$ & $\eta^{2}$ \\
\hline Adolescents & 3.33 & .76 & 3.30 & .80 & group & 11.45 & $<.01$ & .05 \\
\hline Students & 3.47 & .73 & 3.43 & .76 & sex & .55 & .46 & .01 \\
\hline Adults & 3.69 & .70 & 3.63 & .68 & group*sex & .02 & .98 & .01 \\
\hline Generalized & \multicolumn{2}{|c|}{ Males } & \multicolumn{2}{|c|}{ Females } & \multicolumn{4}{|c|}{ ANOVA results } \\
\hline Self-Efficacy & $\mathrm{M}$ & SD & $\mathrm{M}$ & SD & Variables & $\mathrm{F}$ & $\mathrm{p}$ & $\eta^{2}$ \\
\hline Adolescents & 2.91 & .48 & 2.90 & .43 & group & 1.55 & .21 & .01 \\
\hline Students & 3.03 & .41 & 2.88 & .40 & $\operatorname{sex}$ & .093 & .18 & .01 \\
\hline Adults & 3.04 & .48 & 2.92 & .38 & group*sex & .094 & .18 & .01 \\
\hline
\end{tabular}

We estimated all of the hypothesized models and handled missing data by using Mplus 4.01 (Muthén, Muthén, 2006) with maximum likelihood estimation. According to a multifaceted approach to the assessment of model fit (Kline, 1998) the following criteria were employed to evaluate the goodness of fit: chi-square $\left(\chi^{2}\right)$ likelihood ratio statistic, Tucker and Lewis Index (TLI), Comparative Fit Index (CFI), the Root Mean Square Error of Approximation (RMSEA) with associated confidence intervals ( $C I$ with their p values), and the Standardized Root Mean Square Residual (SRMR). We accepted TLI and CFI values higher than 90 (Bentler, 1990), RMSEA values lower than .06 (Brown, Cudeck, 1993), and values lower than .08 for the SRMR. Chi-square difference tests were used to compare nested models $\left(\Delta \chi^{2}\right)$.

Given the moderate size of the three samples used to compare the fit of Model 1 across age groups, and given the relatively large number of indicators, the models were analyzed via item parceling (Hoyle, 1995). Item parcels are likely to increase the stability of parameter estimates, improve the variable to sample size ratio, and reduce the effects of non-normality (see Little et al., 2002). Accordingly, items were randomly combined for each scale into two parcels of two or five items for each dimension, depending on the construct (West, Finch, Curran, 1995). Thus, the final model was composed by height manifest indicators (parcels), represented by 
the individuals' mean scores on items belonging, respectively, to self-esteem, life satisfaction, optimism, and GSE. Each manifest indicator was allowed to load simultaneously on only one latent variable and no crossloading or correlation among residuals was allowed. To make the measurement model just identified, we constrained the loading of both parcels for each first-order factor to equality.

Analyzing the total sample, Model 1 $\left(\chi_{(22)}^{2}=43.83, \mathrm{p}<.01, \mathrm{TLI}=.967, \mathrm{CFI}=.959\right.$, $\mathrm{RMSEA}=.061(\mathrm{CI}=.033-.089), \mathrm{SRMR}=.079)$, as well as Model $2\left(\chi^{2}{ }_{(23)}=69.67, \mathrm{p}<.01\right.$, $\mathrm{TLI}=.968, \mathrm{CFI}=.959, \mathrm{RMSEA}=.057(\mathrm{CI}=$ $.042-.072)$, SRMR $=.076)$, and Model 3 $\left(\chi_{(18)}^{2}=36.05, \mathrm{p}<.01, \mathrm{TLI}=.971, \mathrm{CFI}=.955\right.$, $\mathrm{RMSEA}=.065(\mathrm{CI}=.033-.095), \mathrm{SRMR}=.076)$ fitted the data well. However, the results of model comparisons demonstrated that Model 2 fitted the data considerably worse than Model 3 (the correlated construct model; $\Delta \chi_{(1)}^{2}=25.84, \mathrm{p}<.01$ ), and Model 1 (the positive orientation model; $\Delta \chi_{(1)}^{2}=33.62, \mathrm{p}<.01$ ). This model failed to show a competitive fit compared to the other two models. On the contrary, Model 1, hypothesizing a latent factor of POS correlated with GSE, fitted better than Model 2 and also Model $3\left(\Delta \chi_{(1)}^{2}=\right.$ $7.78, \mathrm{p}=.09)$. Thus, as the positive orientation model (Model 1) was more parsimonious (i.e., had 4 more degrees of freedom than the separated constructs model; Edwards, 2001) the results were preferable to those of the correlated constructs model (Model 3). In this final model (Model 1), all first-order loadings were significant and all above .60 (range: from .63 to .89). The correlation between POS and GSE was .65.

As for the total sample, results demonstrated that the positive orientation model (Model 1) was preferable to Model 2 and
Model 3 in each of the three considered subsamples (Table 2). In all subsamples, all first-order loadings were significant and all above .60 (range: from .61 to .87). The correlations between positive orientation and generalized self-efficacy were .71, .64, and .64 in the samples of adolescents, students, and adults, respectively.

After the best fitting model had been estimated separately for each group, we used multi-group Confirmatory Factor Analyses (CFAs) to examine measurement invariance (Little, 1997). A sequence of nested models was tested (see: Vandenberg, Lance, 2000). In the first (unconstrained) model, the factor loadings, intercepts, and error variances were allowed to differ across groups (configural invariance). In the second model (metric invariance), the factor loadings were constrained to be equal (equal $\lambda$ ) across groups. In the third model, we imposed an additional constraint of equal first-order intercept invariance (scalar invariance: equal $\tau$ ). The latter level of invariance was of special interest because it was required for comparing latent means across groups and referred to the equality of scale's origin between groups. To test the differences between the base model and the more restricted models, we calculated restricted chi-square tests $\left(\Delta \chi^{2}\right)$ with an alpha level of .05 (Bollen, 1989).

Having selected Model 1 as the best-fitting model, we proceeded with examining measurement invariance and estimated that model in all three groups simultaneously. The configural model showed a good fit with the data: $\chi_{(d=66: N=687)}^{2}=101.00, \mathrm{p}<.01, \mathrm{CFI}=.984$, $\mathrm{TLI}=.976, \mathrm{RMSEA}=.045(\mathrm{CI}=.02-.066)$, $\mathrm{SRMR}=.037$. When we constrained the firstorder factor loadings in the measurement model to be equal across the groups, the change in overall chi-square was non-sig- 
Table 2. Results from Model Fitting Analyses

\begin{tabular}{|c|c|c|c|c|c|c|c|c|c|}
\hline $\begin{array}{l}\text { Adolescents } \\
(n=200)\end{array}$ & $\chi^{2}$ & $\mathrm{df}$ & $\mathrm{p}$ & TLI & CFI & SRMR & RMSEA & $\mathrm{CI}$ & $\mathrm{p}$ \\
\hline Model 1 & 45.97 & 22 & $<.01$ & .956 & .972 & .043 & .067 & $.036-.098$ & .16 \\
\hline Model 2 & 58.19 & 23 & $<.01$ & .935 & .956 & .06 & .081 & $.053-.110$ & .04 \\
\hline \multirow[t]{2}{*}{ Model 3} & 36.76 & 18 & .04 & .969 & .985 & .026 & .056 & $.01-.093$ & .35 \\
\hline & $\Delta \chi^{2}$ & & $\Delta d f$ & & $\mathrm{p}$ & & & & \\
\hline Model: 3 vs. 1 & 9.21 & & 4 & & .06 & & & & \\
\hline Model: 3 vs. 2 & 21.43 & & 5 & & $<.01$ & & & & \\
\hline Model: 2 vs. 1 & 12.22 & & 1 & & $<.01$ & & & & \\
\hline $\begin{array}{l}\text { Students } \\
(n=232)\end{array}$ & $\chi^{2}$ & $\mathrm{df}$ & $\mathrm{p}$ & TLI & CFI & SRMR & RMSEA & CI & $\mathrm{p}$ \\
\hline Model 1 & 46.68 & 22 & $<.01$ & .955 & .971 & .037 & .072 & $.038-.105$ & .13 \\
\hline Model 2 & 51.90 & 23 & $<.01$ & .956 & .970 & .040 & .072 & $.038-.104$ & .13 \\
\hline \multirow[t]{2}{*}{ Model 3} & 40.00 & 18 & $<.01$ & .948 & .974 & .029 & .077 & $.040-.115$ & .10 \\
\hline & $\Delta \chi^{2}$ & & $\Delta d f$ & & $\mathrm{p}$ & & & & \\
\hline Model: 3 vs. 1 & 6.68 & & 4 & & .16 & & & & \\
\hline Model: 3 vs. 2 & 11.90 & & 5 & & .04 & & & & \\
\hline Model: 2 vs. 1 & 5.22 & & 1 & & .02 & & & & \\
\hline Adults $(n=240)$ & $\chi^{2}$ & $\mathrm{df}$ & $\mathrm{p}$ & TLI & CFI & SRMR & RMSEA & $\mathrm{CI}$ & $\mathrm{p}$ \\
\hline Model 1 & 27.775 & 22 & .47 & 1.01 & 1.00 & .032 & .00 & $.00-.057$ & .91 \\
\hline Model 2 & 35.728 & 23 & .14 & .984 & .989 & .044 & .038 & $.00-.073$ & .067 \\
\hline \multirow[t]{2}{*}{ Model 3} & 23.76 & 18 & .47 & 1.01 & 1.00 & .026 & .00 & $.00-.062$ & .88 \\
\hline & $\Delta \chi^{2}$ & & $\Delta d f$ & & $\mathrm{p}$ & & & & \\
\hline Model: 3 vs. 1 & 4.02 & & 4 & & .40 & & & & \\
\hline Model: 3 vs. 2 & 11.97 & & 5 & & .04 & & & & \\
\hline Model: 2 vs. 1 & 7.95 & & 1 & & $<.01$ & & & & \\
\hline
\end{tabular}

Note: Model 1: POS correlated with GSE; Model 2: POS loaded by GSE; Model 3: The correlated construct model.

nificant $\Delta \chi_{(8)}^{2}=25.88, \mathrm{p}=.17$. Similarly, constraining the loadings of self-esteem, life satisfaction, and optimism on POS to equality resulted in a non-significant decrease in fit $\Delta \chi_{(2)}^{2}=4.02, \mathrm{p}=.13$. Furthermore, the requirements of metric invariance were satisfied. Then, we also constrained the intercepts for the measurement model. The chi-square difference test between that model and the less constrained model was non-significant $\Delta \chi_{(8)}^{2}=14.76, p=.06$. Likewise, constraining the intercepts of self-esteem, life satisfaction, optimism, and GSE resulted in a non-significant chi-square difference test $\Delta \chi^{2}{ }_{(4)}=5.43$, $\mathrm{p}=.25$. The results of the latter two tests suggested that scalar invariance, also called strong invariance, was reached ${ }^{1}$. Figure 2 presents the standardized parameter estimates for this final model. In the light of these findings, hypothesis 2 is not confirmed.

As the final step, we fixed latent means of positive orientation to equality across the three different groups. The test resulted in a largely significant chi-square difference test, suggesting that latent means should be con-

${ }^{1} \mathrm{We}$ investigated plausible differences in the strength of correlation between POS and GSE across ages by constraining these coefficients to equality, and found a significant chi-square difference $\Delta \chi^{2}(2)=6.81, \mathrm{p}=.047$; POS and GSE were more strongly correlated among adolescents (see Figure 2). 


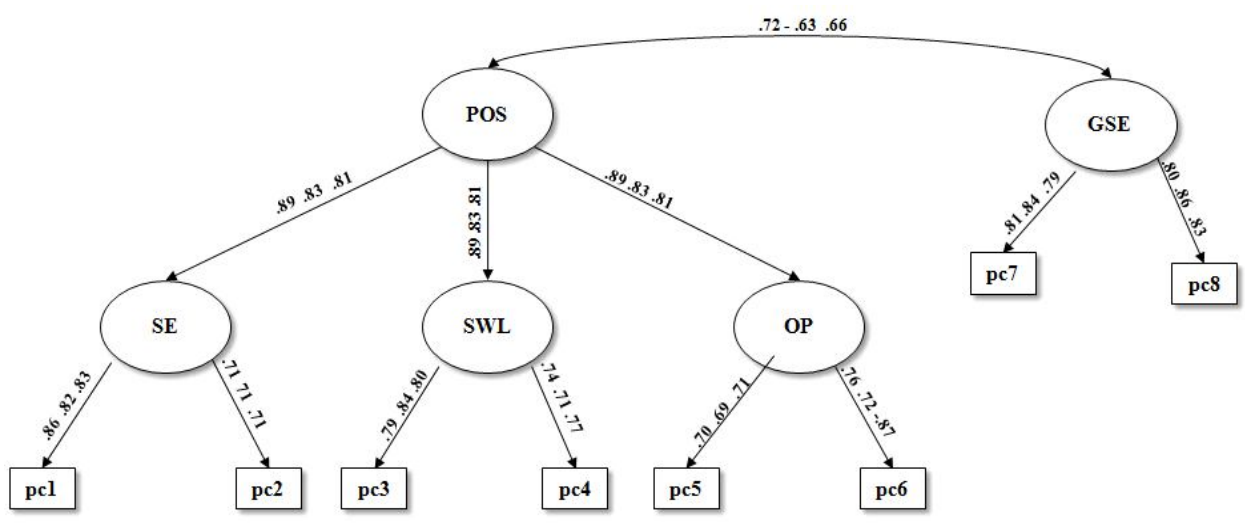

Figure 2. The model of POS with standardized parameter estimates resulting from configural invariance. The first coefficient (from the left) is for adolescents, the second for students, and the third for adults.

Note: $\mathrm{SE}=$ self-esteem; $\mathrm{SWL}=$ life satisfaction; $\mathrm{OP}=$ optimism; $\mathrm{GSE}=$ generalized selfefficacy; Pc1-Pc2: parcels for self-esteem; Pc3-Pc4: parcels for life satisfaction; Pc5-Pc6: parcels for optimism; Pc7-Pc8: parcels for GSE

sidered different: $\Delta \chi_{(2)}^{2}=20.01, \mathrm{p}=<.01$. POS was lower for adolescents $(\mathrm{M}=9.95)$ and higher for young adults $(\mathrm{M}=10.17)$ and adults $(\mathrm{M}=10.44)$, showing a slight increase across ages. Similarly, fixing latent means of GSE to equality resulted in a non-significant chi-square test $\Delta \chi^{2}{ }_{(2)}=2.81, \mathrm{p}=.24$. Therefore, these means should be considered equal.

Aiming to investigate gender differences, we included gender as a covariate of both latent POS and GSE in the previous model (Model 1). The model showed again an adequate fit: $\chi_{(106)}^{2}=246.29, \mathrm{p}<.01, \mathrm{TLI}=.927$, $\mathrm{CFI}=.938, \mathrm{RMSEA}=.077(\mathrm{CI}=.064-.089)$, $\mathrm{SRMR}=.078$. No effect of gender was detected on either POS or GSE in any of the three age groups.

\section{DISCUSSION}

The present study considers the question of whether GSE can be traced together with self-esteem, life satisfaction, and optimism to a common latent dimension, named POS. The present findings corroborate the previous findings tracing self-esteem, life satisfaction, and optimism to POS while leaving GSE as a separate but correlated factor (Caprara, Alessandri, Barbaranelli, 2010). When GSE is added to the earlier triad, the model's fit decreases.

The findings suggest that the views that people hold about themselves, life, and the future reflect a pervasive mode of appraisal while GSE mostly concerns a general sense 
of mastery. This distinction has important practical implications: although POS mostly concerns how people construe themselves within the world, GSE mostly concerns people's beliefs about the control they can exercise over their own lives. Since the previous findings indicate a considerable genetic component in POS, it can be viewed as a basic predisposition to optimal functioning across life domains serving as protective factor against challenges and failures (Caprara et al., 2009). On the other hand, as the previous findings relate self-efficacy beliefs to mastery experiences (Bandura, 1997), GSE can be regarded as a general sense of confidence that may be properly inculcated in a person and reinforced through learning and self-reflection (Hoskovcová, 2006). Likewise, it is the way POS and GSE interplay with one another. Even though inheritance contributes to determining an individual's level of POS (Caprara et al., 2009), it is not solely responsible for any of its manifestations at any particular time or for any associated behavior. The significant contribution of experience should not be underestimated. The present study demonstrates a slight increase of POS from adolescence to adulthood in accordance with the results illustrating that happiness may increase during the mature stages of life (Charles, Reynolds, Gatz, 2001; Diener, Diener, 1995).

As part of the genetic endowment, POS can be considered to be an individual potentiality. The realization of potential in terms of self-esteem, life satisfaction, and optimism depends both on environmental opportunities and on an individual's capacity to master their experiences. Thus, interventions designed to nurture and strengthen a positive view of oneself, one's own life, and the future, without boosting high but insecure and fragile self-esteem (Kernis, 2003) or enhancing unrealistic optimism, represent a major challenge for researchers, clinicians, and health psychologists. Recent findings attest to the malleability of POS and of its components despite a high degree of heritability and stability as well as point to self-efficacy beliefs as effective agents of change. Ultimately, one may view POS as predisposition to GSE and self-efficacy beliefs as the vessels enabling to promote POS. Social cognitive theory (Bandura, 1997) provides an explanatory frame of how predispositions can accord with mastery experiences at the service of optimal functioning. It also offers a unique direction to identify the strategies suitable to enable people to manage their emotions and their interpersonal relationships in ways that strengthen their selfesteem, bring life satisfaction, and allow them to imagine a promising life.

In conclusion, one may view self-efficacy as a close correlate of POS, though not its specific component. Although longitudinal studies are welcome in order to ascertain the plausible directions of influence linking these two constructs, the present results add support to the opinion that individuals who score high on POS feel a stronger confidence in their potentialities and strengths, yet these two sets of beliefs are distinct. Another problem for further study is the hypothetical relationship between POS and core self-evaluations as a trait indicated by self-esteem, locus of control, GSE, and (low) neuroticism (Judge, 2009).

As regards the limitations of this study, almost a quarter of the respondents were married and this issue was not of main interest in this study; however, that fact might have influenced the results. The question of the relationships between POS and marital 
status seems to be an interesting one for further studies. It should be also emphasized that it is beneficial to assess self-esteem, life satisfaction, and optimism using multiple methods, for instance implicit measures and informants, rather than rely on self-reports. The second benefit of extending similar research to specific populations prone to various kinds of health problems is the chance this would offer to further assess the generalizability of posited relations between the constructs discussed in this paper. Also cross-cultural investigations of the models studied would be interesting, especially as other cross-cultural analyses concentrate solely on POS (e.g., Caprara et al., in press).

Received April 15, 2012

\section{REFERENCES}

AKIN, A., KURBANOGLU, I.N., 2011, Relationships between math anxiety, math attitudes, and self-efficacy: A structural equation model. Studia Psychologica, 53, 3, 263-273.

ALESSANDRI, G., CAPRARA, G.V., TISAK, J., 2012, The unique contribution of positive orientation to optimal functioning: Further explorations, European Psychologists, 17, 44-54.

BAGOZZI, R.P. (Ed.), 1994, Principles of marketing research. Cambridge, MA: Blackwell.

BANDURA, A., 1997, Self-efficacy. The exercise of control. New York: Freeman \& Co.

BAUMEISTER, R.F., CAMPBELL, J.D., KRUEGER, J.I., VOHS, K.D., 2003, Does high self-esteem cause better performance, interpersonal success, happiness, or healthier lifestyle? Psychological Science in the Public Interest, 4, 144.

BENTLER, P.M., 1990, Comparative fit indexes in structural equation modelling. Psychological Bulletin, 107, 238-246.

BOLLEN, K.A., 1989, Structural equations with latent variables. New York: Wiley.

BROWNE, M.W., CUDECK, R., 1993, Alternative ways of assessing model fit. In: K.A. Bollen, J.S. Long (Eds.), Testing structural equation models. Newbury Park, CA: Sage.
CAPRARA, G.V., ALESSANDRI, G., BARBARANELLI, C., 2010, Optimal functioning: The contribution of self-efficacy beliefs to positive orientation. Psychotherapy and Psychosomatics, 79, 328-330.

CAPRARA, G.V., ALESSANDRI, G., TROMMSDORFF, G., HEIKAMP, T., YAMAGUCHI, S., SUZUKI, F., in press, Positive orientation across countries. Journal of Cross-Cultural Psychology.

CAPRARA, G.V., FAGNANI, C., ALESSANDRI, G., STECA, P., GIGANTESCO, A., CAVAlli SFORZA, L.L., 2009, Human optimal functioning: The genetics of positive orientation towards self, life, and the future. Behaviour Genetics, 39, 277 284.

CAPRARA, G.V., STECA, P., ALESSANDRI, G., ABELA, J.R.Z., MCWHINNIE, C.M., 2010, Positive orientation: Explorations on what is common to life satisfaction, self-esteem, and optimism. Epidemiologia e Psichiatria Sociale, 19, 63-71.

CARVER, C.S., SCHEIER, M.F., 2002, Optimism. In: C.R. Snyder, J.L. Lopez (Eds.), Handbook of positive psychology (pp. 231-243). New York: Oxford University Press.

CHARLES, S.T., REYNOLDS, C.A., GATZ, M., 2001 , Age-related differences and change in positive and negative affect over 23 years. Journal of Personality and Social Psychology, 80, 136-151.

CSIKSZENTMIHALYI, M., 2009, The promise of positive psychology. Psychological Topics, 18, 203-211.

DIENER, E., 1984, Subjective well-being. Psychological Bulletin, 95, 542-575.

DIENER, E., DIENER, M., 1995, Cross-cultural correlates of life satisfaction and self-esteem. Journal of Personality and Social Psychology, 68, 653663.

DIENER, E., EMMONS, R.A., LARSEN, R.J., GRIFFIN, S., 1985, The Satisfaction With Life Scale. Journal of Personality Assessment, 49, 7175 .

EDWARDS, J.R., 2001, Multidimensional constructs in organizational behavior research: An integrative analytical framework. Organizational Research Methods, 4, 144-192.

FRYDENBERG, E., 2008, Adolescent coping. Advances in theory, research and practice. London: Routledge.

HECKHAUSEN, J., 1999, Developmental regulation in adulthood. Age-normative and sociostructural constrains as adaptive challenges. Cambridge: Cambridge University Press. 
HOSKOVCOVÁ, S., 2006, Self-efficacy in preschool children. Studia Psychologica, 48, 175-182.

HOYLE, R.H. (Ed.), 1995, Structural equation modeling. Thousand Oaks, CA: SAGE Publications, Inc.

JONES, T.G., RAPPORT, L.J., HANKS, R.A., LICHTENBERG, P.A., TELMET, K., 2003, Cognitive and psychosocial predictors of subjective wellbeing in urban older adults. Clinical Neuropsychologist, 17, 3-18.

JOMBÍKOVÁ, E., KOVÁČ, D., 2007, Optimism and quality of life in adolescents - Bratislava secondary schools students. Studia Psychologica, 49, 347-356.

JUDGE, T.A., 2009, Core self-evaluations and work success. Current Directions in Psychological Science, 18, 58-62.

KERNIS, M.H., 2003, Toward a conceptualization of optimal self-esteem. Psychological Inquiry, 14, 1-26.

KLINE, R.B., 1998, Principles and practices of structural equation modeling. New York: Guilford.

LAGUNA, M., in press, Self-efficacy, self-esteem, and entrepreneurship amongst the unemployed. Journal of Applied Social Psychology.

LITTLE, T., 1997, Mean and covariance structures (MACS) analyses of cross-cultural data: Practical and theoretical issues. Multivariate Behavioral Research, 32, 53-76.

LITTLE, T.D., CUNNINGHAM, W.A., SHAHAR, G., WIDAMAN, K.F., 2002, To parcel or not to parcel: Exploring the question, weighing the merits. Structural Equation Modeling, 9, 151173.

LUSZCZYNSKA, A., SCHOLZ, U., SCHWARZER, R., 2005, The General Self-Efficacy Scale: Multicultural validation studies. The Journal of Psychology, 139, 439-457.

LYUBOMIRSKY, S., KING, L., DIENER, E., 2005, The benefits of frequent positive affect: Does happiness lead to success? Psychological Bulletin, 131, 803-855.

MAGALETTA, P.R., OLIVER, J.M., 1999, The hope construct, will, and ways: The relations with self-efficacy, optimism, and general well-being. Journal of Clinical Psychology, 55, 539-551.

MUTHÉN, L.K., MUTHÉN, B.O., 2006, Mplus User's Guide. Los Angeles: Muthen \& Muthen.

REW, L., 2005, Adolescent health. A multidisciplinary approach to theory, research, and intervention. Thousand Oaks: SAGE Publications.
ROSENBERG, M., 1989, Society and the adolescent self-image. Princeton, NJ: Princeton Univ. Press.

SARMÁNY-SCHULLER, I., 1993, Different problem solving strategies (What role is played by optimism-pessimism here?). Studia Psychologica, 35, 377-379

SCHEIER, M.F., CARVER, C.S., BRIDGES, M.W., 1994, Distinguishing optimism from neuroticism (and trait anxiety, self-mastery, and self-esteem): A reevaluation of the Life Orientation Test. Journal of Personality and Social Psychology, 67, 10631078.

SCHIMMACK, U., DIENER, E., 2003, Predictive validity of explicit and implicit self-esteem for subjective well-being. Journal of Research in Personality, 37, 100-106.

SCHWARZER, R. (Ed.), 1992, Self-efficacy. Thought control of action. Washington, DC: Hemisphere.

SCHWARZER, R, JERUSALEM, M., 1995, Generalized Self-Efficacy Scale. In: J. Weinman, S. Wright, M. Johnston (Eds.), Measures in health psychology: A user's portfolio. Causal and control beliefs (pp. 35-37). Windsor: UK: Nfer-Nelson.

SEMMER, N.K., 2006, Personality, stress and coping. In: M.E. Vollrath, Handbook of personality and health (pp. 73-113). Chichester: Wiley and Sons.

SHELDON, K.M., 2009, Providing the scientific backbone for positive psychology: A multilevel conception of human thriving, Psychological Topics, 18, 267-284.

SOLLÁROVÁ, E., SOLLÁR, T., 2010, The psychologically integrated person and the parameters of optimal functioning. Studia Psychologica, 5, 333-338.

VANDENBERG, R.J., LANCE, C.E., 2000, A review and synthesis of the measurement invariance literature: Suggestions, practices, and recommendations for organizational research. Organizational Research Methods, 2, 4-69.

WEST, S.G., FINCH, J.F., CURRAN, P.J., 1995, Structural equation models with non-normal variables: Problems and remedies. In: R. Hoyle (Ed.), Structural equation modeling: Concepts, issues, and applications (pp. 56-75). Thousand Oaks, CA: Sage.

ŽITNÝ, P., HALAMA, P., 2011, Self-esteem, locus of control, and personality traits as predictors of sensitivity to injustice. Studia Psychologica, $53,1,27-40$ 


\section{POZITÍVNA ORIENTÁCIA A GENERALIZOVANÁ SEBAÚČINNOSŤ}

P. K. O l e ś, G. A le s s a n d ri, M. O le ś, W. B a k, T. J a n k o w s k i, M. L a gu n a, G. V. C a p r a r a

Súhrn: Čo si l’udia myslia o sebe, o svojom živote a budúcnosti, sú dôležité a vzájomne prepojené zložky psychologického fungovania a životnej pohody. V našom príspevku sme skúmali vzt'ah medzi pozitívnou orientáciou a generalizovanou sebaúčinnost'ou. Výskumu sa zúčastnilo 672 respondentov vo veku 15-27 rokov (274 mužov). Výsledky potvrdili prvú hypotézu, podl'a ktorej pozitívna orientácia a generalizovaná sebaúčinnost’ tvoria dva rozdielne konštrukty, ktoré však vzájomne súvisia. Výsledky sa potvrdili v troch vekových skupinách, v rozpore s druhou hypotézou sa vek ako moderátor vzt'ahu medzi pozitívnou orientáciou a vlastnou účinnost'ou nepotvrdil. 